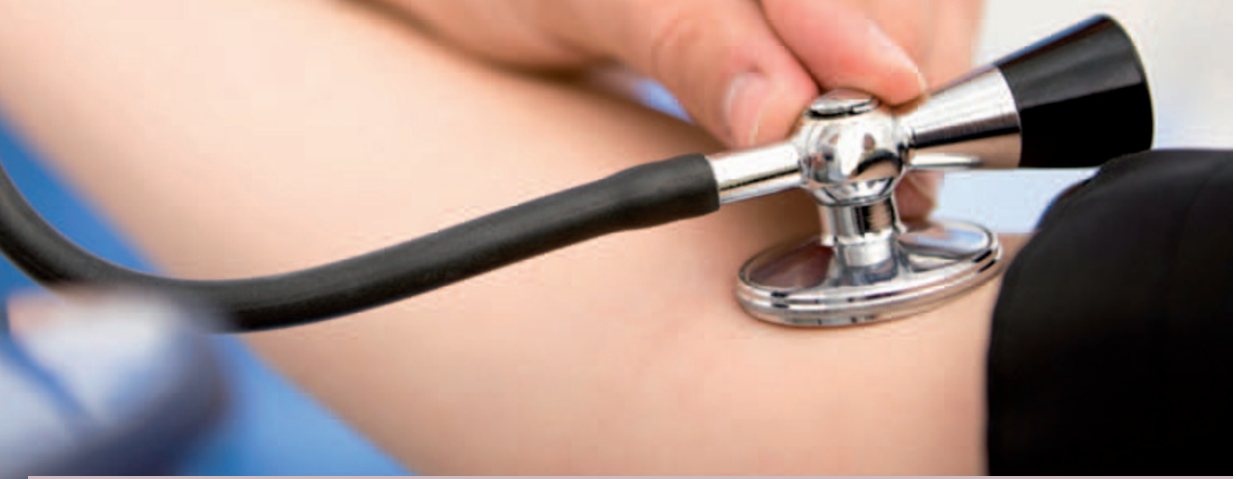

\section{MANCHESTER PRACTICE FIGHTS SILENT KILLER}

A dental practice in Manchester has lent their support to the Blood Pressure Association's 'Know your Numbers!' week in September - a campaign directed towards the public understanding healthy blood pressure. The Mall Advanced Dental Care offered a free blood pressure check to all their patients during Know your Numbers! week.

'We always fully record our patients' medical history when providing dental treatment, but we are keen to help them take a holistic approach to their health', said Chloe Booth of The Mall Advanced Dental Care. 'City living, stress and work pressures can increase blood pressure issues, and Know your Numbers! week is a fantastic campaign for city-dwellers to focus their minds on looking after their own health'.

One in three adults in the UK has high blood pressure which is the biggest known cause of premature death and disability in the UK due to the strokes, heart attacks and heart disease it can cause. More than 5 million people don't know that they have high blood pressure, which is why it's called the silent killer.

'Many of our patients are movers and shakers in the financial industry here in Manchester, and we're hearing reports about massively increasing stress levels in line with the credit crunch,' said Chloe. 'Signs of stress are often presented in the mouth, for example teeth grinding, and we can also help people relax by treating some of these other issues.'

To find out more about the Blood Pressure Association visit http://www.bpassoc.org.uk/ microsites/kyn/Home

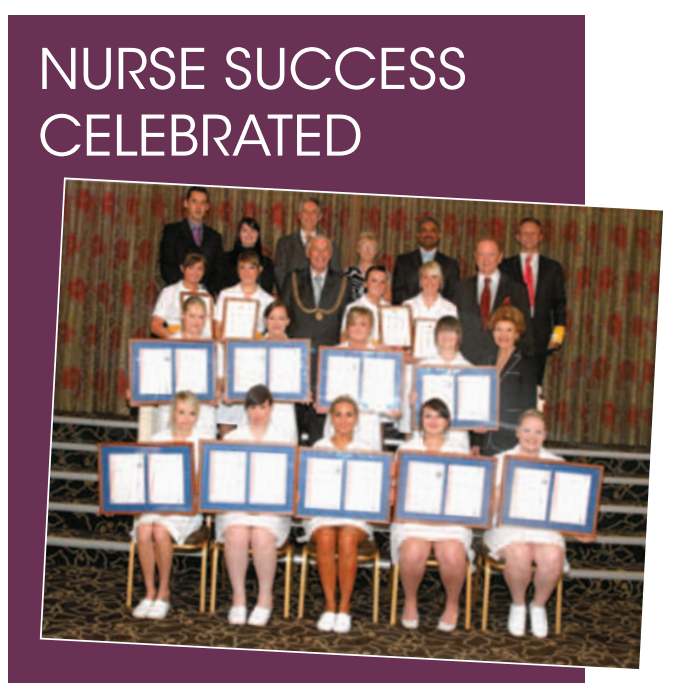

On 5 October J. G. Plummer \& Associates held their celebration of dental nurse achievement qualifications at the Imperial Hotel Great Yarmouth. Framed City \& Guilds or NEBDN certificates were presented to successful dental nurse candidates as well as postqualification awards in dental radiology to trained nurses.

\section{ARF WILL NOT RISE IN 2012}

Dentists and dental care professionals (DCPs) will see no increase in their registration fees in 2012 following a decision by the General Dental Council (GDC).

This means dentists will pay $£ 576$ by 31 December 2011 and DCPs will pay $£ 120$ by 31 July 2012.

\section{KATE MIDDLETON'S SMILE}

Caroline Holland on a lingual dilemma. What happens if you are credited with providing treatment to a famous person when you are not the clinician and can claim no part in the transformation?

The potential dilemma comes in the wake of stories about Kate Middleton's smile. According to some royal commentators, Kate benefited from lingual treatment before her big day. Indeed, several orthodontists have been associated with her in the popular media. Sarah Hepburn of the Harley Street Orthodontic Clinic was quoted in Hello in an article describing the lingual technique and featuring a picture of Kate Middleton. It wasn't suggested in the article that Dr Hepburn treated the Duchess, but it could be inferred that she did.

The fact is, Dr Hepburn is an authority on the lingual technique and Secretary of the British Lingual Orthodontic Society. She would be a likely choice. Soren Holm, Professor of Bioethics at Manchester University, commented: 'In PR terms, having treated Kate Middleton or having claims made that you did is not a bad thing. There is no professional or moral obligation to deny you have done something:'

Stories about celebrities are inevitably embarrassing because the clinician does not want to be perceived to be breaching confidentiality. Indeed any attempt to make a press statement denying you have done something could make the situation worse. It could give more publicity when the person concerned would rather the story died down. And you might not be believed anyway.

Professor Holm continued: 'While you do have a strong right to disassociate yourself from something that has been done, no-one might believe you. In the case where it is true you could find yourself charged with

breaching

confidentiality

and blatant

self-promotion.

I would lean

towards

not saying

anything:

Lingual

orthodontics

is now a

technique

widely taken up
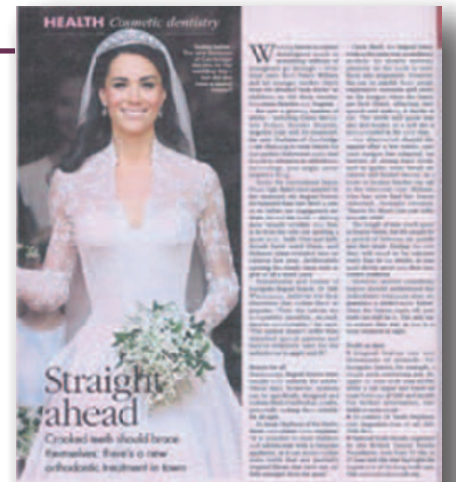

around the UK. The beautiful and famous

have been in the vanguard. Models,

actresses, TV presenters and now, possibly,

royalty. But please note the doubt here. I

really don't know who treated Kate or if indeed she had treatment. But if she did, a member of BLOS (the British Lingual Orthodontic Society) would be a very good start! www.blos.co.uk 